\title{
PROGNOSTIC VALUE OF TOPOISOMERASE 2-ALPHA AND B-MYB IN EARLY BREAST CANCER TREATED WITH ADJUVANT CHEMOTHERAPY
}

\author{
Ljubica Radmilović Varga ${ }^{1}$, Natalija Dedić Plavetiće, ${ }^{2,3}$ Paula Podolski ${ }^{2}$, \\ Davor Mijatović ${ }^{3,4}$, Ana Kulić ${ }^{5}$ and Damir Vrbanec ${ }^{6}$ \\ ${ }^{1}$ Department of Pulmonology, Varaždin General Hospital, Klenovnik, Croatia; \\ ${ }^{2}$ Department of Oncology, Division of Medical Oncology, Zagreb University Hospital Centre, Zagreb, Croatia; \\ ${ }^{3}$ School of Medicine, University of Zagreb, Zagreb, Croatia; \\ ${ }^{4}$ Department of Surgery, Zagreb University Hospital Centre, Zagreb, Croatia; \\ ${ }^{5}$ Department of Pathophysiology, Zagreb University Hospital Centre, Zagreb, Croatia; \\ ${ }^{6} J u r a j$ Dobrila University of Pula, Pula, Croatia
}

\begin{abstract}
SUMMARY - Breast cancer is the most common malignancy in females. Despite its well-established prognostic factors, our prognostic ability at an individual patient level remains limited. In this study, the immunohistochemical expression of B-Myb and DNA topoisomerase 2-alpha (Topo2a) was analyzed in primary tumors to identify patients with a higher risk of disease recurrence after adjuvant chemotherapy for early invasive breast cancer. We analyzed a cohort of 215 early invasive breast cancer patients having undergone surgery from 2002 to 2003 at the Zagreb University Hospital Centre, including 153 patients treated with adjuvant chemotherapy. All of them were followed-up prospectively for at least ten years according to routine institutional practice. Statistically significant correlations were found between B-Myb and Topo2a expression levels and particular well-established prognostic factors. B-Myb expression was lower in estrogen receptor (ER)-positive tumors ( $\mathrm{p}=0.0773$ ), whereas larger tumors and those with positive lymphovascular invasion displayed a statistically significantly higher B-Myb expression ( $\mathrm{p}=0.0409$ and $\mathrm{p}=0.0196$ ). Higher tumor grade indicated higher Topo $2 \mathrm{a}$ values $(\mathrm{p}=0.0102$ and $\mathrm{p}=0.0069)$. The subgroup with the expression of both proteins above the median value had an almost statistically significantly $(p=0.0613)$ inferior prognosis compared to the rest of the cohort. Study results showed the B-Myb and Topo2a expression to have a prognostic value in breast cancer patients after adjuvant chemotherapy, which should be additionally explored in future studies in a larger patient cohort.
\end{abstract}

Key words: Breast cancer, prognosis, outcome; Adjuvant chemotherapy; B-Myb; Topo2a

\section{Introduction}

Breast cancer is a histologically, molecularly, and clinically heterogeneous disease, with molecular subgroups having different therapeutic approaches, prognosis, and response to therapy. Tumor metastatic potential is determined by several prognostic factors such

Correspondence to: Assist. Prof. Natalija Dedic Plavetic, $M D, P h D$, Zagreb University Hospital Centre, Kišpatićeva 12, HR-10000 Zagreb, Croatia

E-mail: ndedic@kbc-zagreb.hr

Received March 27, 2020, accepted February 12, 2021 as steroid receptor expression, HER-2/neu expression, and $\mathrm{Ki}-67$ proliferation index.

In recent years, tumor proliferation markers and proliferative activity have been extensively investigated as potential survival and treatment response markers in breast cancer. Proliferative activity can be determined by several methods such as mitotic index, 3H-thymidine index, flow-cytometry (detecting the number of cells in S-phase), immunohistochemistry methods (detecting cell cycle-specific proteins), and more recently, gene expression profiling studies ${ }^{1,2}$. 
The B-Myb is a transcription factor involved in cell cycle progression. Numerous cytogenetic analyses have identified $B-M Y B$ amplification or overexpression in breast $^{3}$, liver ${ }^{4}$ and ovarian carcinomas ${ }^{5}$, as well as cutaneous T lymphomas ${ }^{6}$. Higher levels of B-Myb are associated with shortened overall survival (OS) and poor prognosis in breast cancer patients ${ }^{7}$. B-Myb expression is a sign of aggressive breast cancer and its overexpression in different breast cancer subtypes is associated with a significantly shortened OS in locally treated luminal A, luminal B, and HER2+/ER- breast cancers ${ }^{8}$.

Topoisomerase 2-alpha (Topo2a) is a nuclear enzyme that controls topologic structure of DNA during transcription ${ }^{9}$. It is highly expressed in proliferating cells and consecutively correlates with malignancy. Additionally, TOP2 $A$ amplification leading to Topo2a overexpression results in an improved response to Topo2a inhibitors, whereas its deletion results in primary resistance to them ${ }^{10-12}$. Therefore, TOP $2 A$ has been extensively studied in breast ${ }^{13}$, prostate $^{14}$, gastric ${ }^{15}$, and ovarian cancer ${ }^{16}$.

Several studies have shown that Topo2a overexpression served as a predictor of shorter disease-free survival (DFS), as well as specific survival and OS rates $^{17-20}$. Also, Topo2a expression was analyzed in different breast cancer subtypes, with highly proliferative subtypes (triple negative, luminal $\mathrm{B}$, and HER2) expressing higher levels of Topo2a, which is also a sign of breast cancer aggressiveness and worse prognosis ${ }^{13,21}$.

This study aimed to select patients and analyze their B-Myb and Topo2a expression levels to predict response to adjuvant therapy and outcomes. Such an approach would enable us to stratify patients into subgroups for escalation and de-escalation of adjuvant systemic treatment and select patients with poor prognosis for the implementation of novel adjuvant systemic therapy regimens.

\section{Materials and Methods}

\section{Breast carcinoma patient cohort characteristics}

Paraffin-embedded tumor tissue samples were obtained from a consecutive series of 215 patients referred to the Zagreb University Hospital Centre, Zagreb, Croatia, for primary surgical treatment (either mastectomy or quadrantectomy with axillary dissec- tion) due to invasive breast carcinoma between September 2002 and September 2003. Adjuvant radiation therapy was performed according to the guidelines valid at the time this study began. Patients received adjuvant chemotherapy if axillary lymph node involvement was present or absent with the presence of other poor prognostic factors (high tumor grade, large tumors, lymphovascular invasion, lack of hormone receptor expression) and adjuvant endocrine blockade as indicated by the hormone receptor status. Out of 215 patients, only those treated with adjuvant chemotherapy were included in the study $(\mathrm{N}=153)$, with prior neoadjuvant therapy as an exclusion criterion. Lowrisk patients were not treated with adjuvant chemotherapy and were thus excluded. All patients were regularly followed-up for at least ten years, according to routine standard institutional practice and with local recurrence, distant metastases, or death as primary outcomes. Data on ten-year OS and DFS were collected. Archival tumor tissue and follow-up information were collected with the Institutional Review Board approval.

For all patients, data on tumor size, surrogate subtype, tumor grade (nuclear and histologic), HER-2 status, hormone receptor expression (estrogen and progesterone receptor, ER and PR), axillary lymph node involvement, lymphovascular invasion, and adjuvant treatment were obtained ${ }^{22,23}$. Immunohistochemistry for ER (H7096, Dako, Glostrup, Denmark), PR (M3569, Dako, Glostrup, Denmark), and HER2 (Herceptest, Dako, Glostrup, Denmark) was performed on formalin-fixed, paraffin-embedded tissue slides with standard avidin-biotin immunoperoxidase staining method on a Tech Mate automatic stainer (Dako, Glostrup, Denmark). Evaluation of staining results was similar to that used in routine diagnostics, and samples were considered positive when $10 \%$ of the cells were stained with ER and PR. For HER2 status, tumors were considered positive if they scored 3+ according to the HercepTest criteria, and dual silver in situ hybridization (SISH) with amplification at a ratio of $\geq 2.0$ was used to segregate immunohistochemically equivocal $(2+)$ results.

\section{Tissue microarray blocks and immunohistochemical expression of Ki-67, B-Myb, and topoisomerase 2-alpha}

Expression of Ki-67, B-Myb, and Topo2a was analyzed by immunohistochemical (IHC) staining on tis- 
Table 1. Correlations of $B-M y b$ and Topo-2a expression with other clinicopathologic variables

\begin{tabular}{|l|l|l|l|l|l|l|l|l|}
\hline & \multicolumn{2}{|c|}{ Tumor size $(\mathrm{n}=153)$} & \multicolumn{2}{c|}{ Ki67 $(\mathrm{n}=151)$} & \multicolumn{2}{c|}{ DFS $(\mathrm{n}=60)$} & \multicolumn{2}{c|}{ OS $(\mathrm{n}=152)$} \\
\cline { 2 - 10 } & $\mathrm{Sr}$ & $\mathrm{p}$ & $\mathrm{Sr}$ & $\mathrm{p}$ & $\mathrm{Sr}$ & $\mathrm{p}$ & $\mathrm{Sr}$ & $\mathrm{p}$ \\
\hline Topo2a & 0.0017 & 0.9827 & 0.2590 & $0.0013^{*}$ & -0.4307 & $0.0005^{*}$ & -0.2425 & $0.0023^{*}$ \\
B-Myb & 0.1884 & $0.0196^{*}$ & -0.0164 & 0.8414 & -0.1422 & 0.2781 & -0.1601 & $0.0486^{*}$ \\
\hline
\end{tabular}

* $\mathrm{p}<0.05 ;$ DFS = disease-free survival; OS = overall survival; $\mathrm{Sr}=$ Spearman correlation coefficient $\mathrm{r}$

sue microarray (TMA) blocks ${ }^{24}$. A special needle (SAKURA, Japan) was used to punch the highest cellular density area of the primary tumor to build the tissue microarray with three cores of $0.2 \mathrm{~cm}$ in diameter from each primary tumor paraffins. The Manual Arrayer (Beecher Instruments, Sun Prairie, Wisconsin, USA) was used to re-embed the cores into blank recipient blocks with 60 samples on a single slide ${ }^{25,26}$. Sections $(5 \mu \mathrm{m})$ were cut and mounted on a glass slide, deparaffinized in xylene, and rehydrated in a graded alcohol series. For antibody incubation, different dilutions were used, i.e. anti-topoisomerase 2-alpha antibody (Abcam, clone EP1102Y, 1:100), anti-phosphoB-Myb (Epitomics, Thr 487, clone EPR2204Y,1:200), and MIB-1 (Dako, Glostrup, Denmark) antibody (1:50). The automated stainer standard protocol (Dako Universal Staining System, Glostrup, Denmark) was used and diaminobenzidine (DAB) was used for staining visualization on a section counter stained with hematoxylin. Palatal tonsil tissue was used as a positive control for B-Myb, and HeLa cell lysate for Topo2a. Breast cancer tissue slides incubated without primary antibody served as negative controls. Staining results were presented as the percentage of cells with positive nuclear staining for Ki-67 and Topo2a, and cytoplasmic and nuclear staining for B-Myb, as indicated in the manufacturer's instructions.

\section{Statistical analyses}

Statistical analyses were performed using Statistica 6.0 software. Values of Ki-67, B-Myb, and Topo2a were provided as continuous variables. Non-parametric tests (ANOVA, Kruskal-Wallis, Mann-Whitney U test) were carried out to test for differences in B-Myb and Topo2a expression according to other clinicopathologic variables (nodal status, histologic grade, and HR status). Correlations of B-Myb and Topo2a with other continuous variables were tested using Spearman's test. The Kaplan-Meier method was used to generate univariate survival curves. The Gehan-Wilcoxon test was used to assess differences in DFS and OS as co-primary endpoints. The level of statistical significance was set at $\mathrm{p}<0.05$.

\section{Results}

We analyzed the relationship between B-Myb and Topo2a expression and clinicopathologic characteristics, along with the early breast cancer outcomes in a subgroup of 153 women treated with systemic adjuvant chemotherapy. The majority of breast carcinoma patients were older than $50(60.8 \%)$ and postmenopausal (56.2\%) at the time of diagnosis. Most tumors were T2 according to the TNM classification (58.2\%). Histologic tumor grades were predominantly 2 (44.4\%) and 3 (44.4\%), and positive axillary lymph nodes were found in less than $50 \%$ of patients. Positive hormone receptors were found in $60.5 \%$ and $51 \%$ of patients for ER and PR, respectively. This study was conducted before the era of adjuvant trastuzumab; therefore, HER-2 positive tumors were not treated with it.

\section{Association of B-Myb and Topo2a expression with other clinical and pathologic tumor characteristics}

In this cohort, the median B-Myb expression value was 12 , while that of Topo2a was 22 . In addition, there was a positive correlation between Ki-67 and Topo2a expression levels ( $\mathrm{p}=0.0013)$ (Table 1). We found no association between B-Myb and $\mathrm{Ki}-67$ expression. BMyb expression was significantly associated with tumor size, whereby larger tumors showed higher BMyb expression ( $\mathrm{p}=0.0196)$ (Table 1$)$. Higher histologic and nuclear grades (grades 2 and 3 ) displayed higher Topo2a values $(\mathrm{p}=0.0102$ and $\mathrm{p}=0.0069$, respectively) (Table 2). B-Myb expression was lower in ER-positive tumors, without a statistically significant difference $(\mathrm{p}=0.0773)$ (Table 2). A significantly higher 
Table 2. B-Myb and Topo-2a expression according to other clinicopathologic variables (Mann-Whitney U test)

\begin{tabular}{|c|c|c|c|c|c|c|c|c|}
\hline & \multirow{2}{*}{ Median } & \multirow{2}{*}{ Min } & \multirow{2}{*}{ Max } & \multirow{2}{*}{ SD } & \multirow{2}{*}{$\begin{array}{l}\text { Mean } \\
\text { rank }\end{array}$} & \multicolumn{2}{|c|}{ MWU } \\
\hline & & & & & & & $\mathrm{U}$ & $\mathrm{p}$ \\
\hline \multirow{3}{*}{$\begin{array}{l}\text { Lymphovascular } \\
\text { invasion } \\
\text { positive vs. negative }\end{array}$} & & 35.00 & 8.00 & 90.00 & $\begin{array}{l}26.72 \\
2629\end{array}$ & 37.00 & 606.00 & 0.2164 \\
\hline & B-Myb & 25.00 & 2.00 & 80.00 & 20.98 & 28.45 & & \\
\hline & & 11.00 & 0.00 & 90.00 & 21.92 & 19.30 & 492.00 & $0.0409^{*}$ \\
\hline \multirow[t]{3}{*}{$\begin{array}{l}\text { Estrogen receptor } \\
\text { positive } v s . \text { negative }\end{array}$} & Topo2a & $\begin{array}{l}20.00 \\
25.50\end{array}$ & $\begin{array}{l}0.00 \\
2.00\end{array}$ & $\begin{array}{l}95.00 \\
90.00\end{array}$ & $\begin{array}{l}24.50 \\
28.62\end{array}$ & $\begin{array}{l}27.99 \\
34.83\end{array}$ & 2471.50 & 0.2762 \\
\hline & B-Myb & 10.00 & 0.00 & 90.00 & 22.05 & 18.54 & & \\
\hline & & 15.00 & 0.00 & 90.00 & 24.50 & 22.21 & 2292.00 & 0.0773 \\
\hline \multirow{4}{*}{$\begin{array}{l}\text { Nuclear grade } \\
2 \text { vs. } 3\end{array}$} & Topo2a & 15.00 & 0.00 & 90.00 & 24.70 & 25.31 & & $0 \cap 0069^{*}$ \\
\hline & & 30.00 & 2.00 & 90.00 & 25.73 & 35.25 & 1937.50 & 0.0069 \\
\hline & B-Myb & 12.00 & 0.00 & 90.00 & 22.51 & 20.04 & & \\
\hline & & 11.50 & 0.00 & 90.00 & 22.08 & 20.60 & 2597.00 & 0.9336 \\
\hline \multirow[t]{3}{*}{$\begin{array}{l}\text { Histologic grade } \\
2 \text { vs. } 3\end{array}$} & & $\begin{array}{l}15.00 \\
32.50\end{array}$ & $\begin{array}{l}0.00 \\
2.00\end{array}$ & $\begin{array}{l}90.00 \\
90.00\end{array}$ & $\begin{array}{l}23.56 \\
25.69\end{array}$ & $\begin{array}{l}25.20 \\
35.50\end{array}$ & 1937.50 & $0.0102^{*}$ \\
\hline & B-Myb & 12.00 & 1.00 & 90.00 & 22.46 & 19.59 & & \\
\hline & & 12.00 & 0.00 & 90.00 & 21.49 & 19.63 & 2244.50 & 0.7685 \\
\hline \multirow[t]{3}{*}{$\begin{array}{l}\text { Ki67 } \\
\leq 20 \% \text { vs. }>20 \%\end{array}$} & & $\begin{array}{l}15.00 \\
43.50\end{array}$ & $\begin{array}{l}0.00 \\
15.00\end{array}$ & $\begin{array}{l}95.00 \\
90.00\end{array}$ & $\begin{array}{l}25.31 \\
21.51\end{array}$ & $\begin{array}{l}26.53 \\
51.34\end{array}$ & 675.00 & $0.0000^{*}$ \\
\hline & B-Myb & 12.00 & 0.00 & 90.00 & 22.91 & 21.10 & & \\
\hline & & 12.00 & 2.00 & 70.00 & 16.59 & 15.58 & 1510.50 & $0.5 / 25$ \\
\hline \multirow[t]{4}{*}{ Died vs. alive } & Topo2a & 26.00 & 2.00 & 90.00 & 26.06 & 34.25 & 1978.50 & 0.1241 \\
\hline & & 20.00 & 0.00 & 95.00 & 26.29 & 28.88 & $19 / 8.50$ & 0.1241 \\
\hline & B-Myb & 14.50 & 2.00 & 90.00 & 24.82 & 24.77 & 187800 & 0.0512 \\
\hline & & 10.00 & 0.00 & 90.00 & 19.96 & 17.34 & $18 / 8.00$ & 0.0512 \\
\hline \multirow{3}{*}{$\begin{array}{l}\text { Relapsed } \\
\text { vs. } \\
\text { nonrelapsed }\end{array}$} & Topo2a & $\begin{array}{l}18.00 \\
25.00\end{array}$ & $\begin{array}{l}2.00 \\
0.00\end{array}$ & $\begin{array}{l}90.00 \\
95.00\end{array}$ & $\begin{array}{l}24.77 \\
27.14\end{array}$ & $\begin{array}{l}28.05 \\
3179\end{array}$ & 2588.50 & 0.5179 \\
\hline & B-Myb & 13.00 & 2.00 & 90.00 & 25.02 & 23.56 & & \\
\hline & & 9.00 & 0.00 & 80.00 & 19.30 & 17.32 & 2260.00 & 0.0594 \\
\hline \multirow[t]{2}{*}{ Died } & $\begin{array}{l}\text { Anthracyclines } \\
(\mathrm{n}=31)\end{array}$ & 63.00 & 9.00 & 144.00 & 35.11 & 61.83 & 107.50 & $0.0155^{*}$ \\
\hline & $\begin{array}{l}\text { No anthracyclines } \\
(\mathrm{n}=13)\end{array}$ & 20.00 & 5.00 & 117.00 & 39.38 & 35.84 & & \\
\hline
\end{tabular}

*p $<0.05 ;$ MWU = Mann-Whitney U test; $\mathrm{SD}=$ standard deviation

expression of B-Myb was found in patients with lymphovascular invasion ( $\mathrm{p}=0.0409)$ (Table 2).

\section{Influence of B-Myb and Topo2a expression on clinical outcomes}

Disease-free survival

At ten-year follow-up, almost 38\% of patients had relapsed, with the majority of them relapsing in the first five years. DFS was 69.28\% and 62.09\% at fiveand ten-year follow-up, respectively (Fig. 1B). B-Myb expression was higher in patients who relapsed than it was in those who did not, but this difference was at the border of statistical significance $(\mathrm{p}=0.0591)$ (Table 2). Topo2a expression has been associated with the occurrence of relapses. A higher level of Topo2a protein was associated with a shorter time to relapse $(\mathrm{p}=0.000591)$ (Table 1).

\section{Overall survival}

In this cohort, the 5-year OS was $83.7 \%$ (25 patients died) and 10-year OS 71.9\% (43 patients died, 
A. Overal Survival

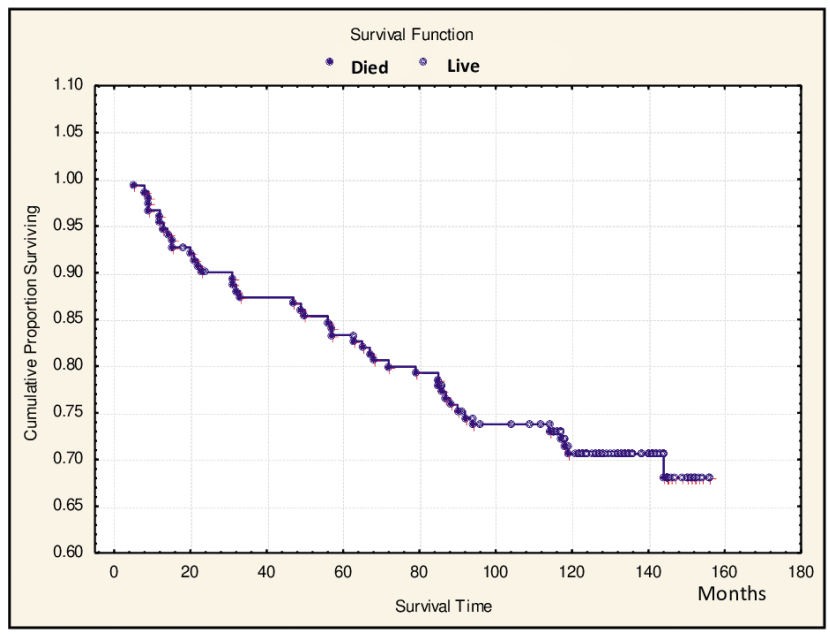

B. Disease-free survival

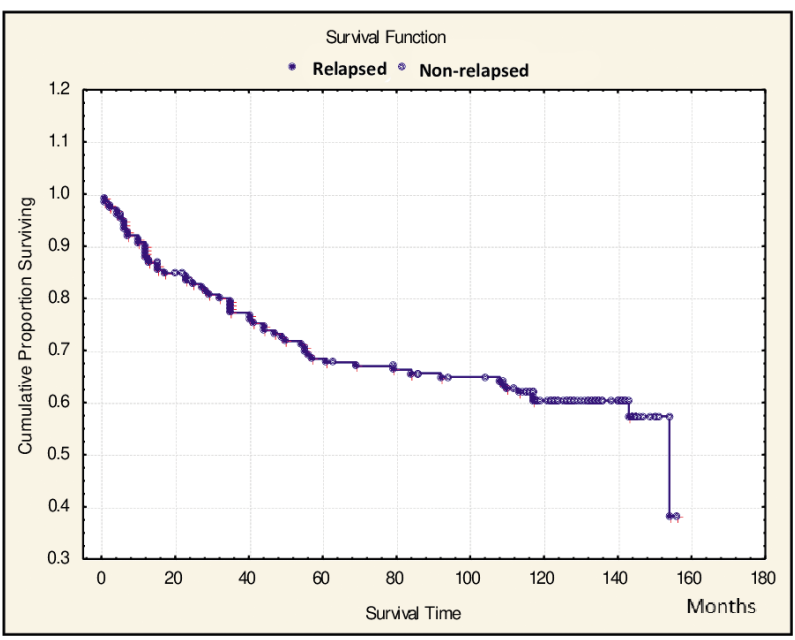

Fig. 1. Ten-year overall survival $(A)$ and disease-free survival (B) in the whole cohort $(N=153)$.

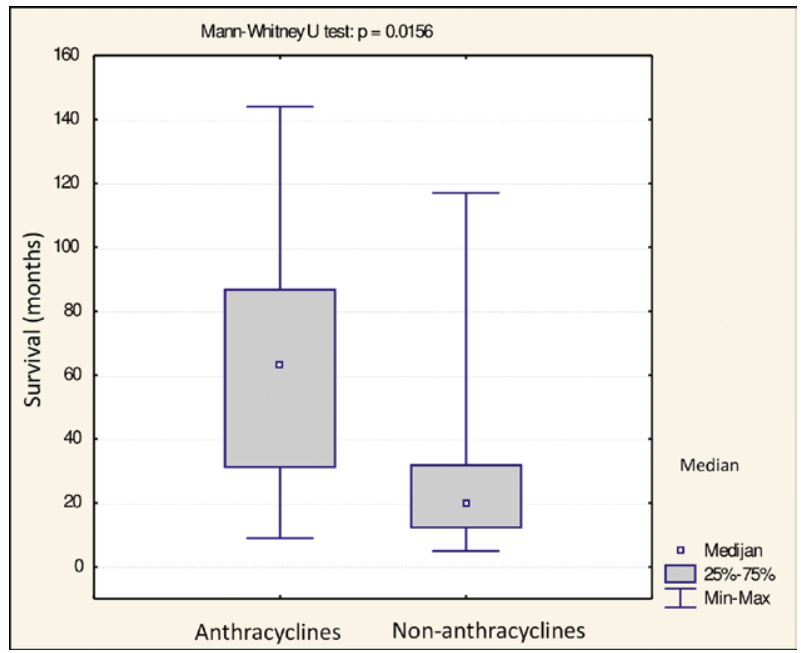

Fig. 2. Length of survival among patients who died according to chemotherapy regimen (anthracycline vs. non-anthracycline).

whereas $58.1 \%$ of them died during the first five years after surgery). More than $80 \%$ of relapses and more than $58 \%$ of deaths occurred in the first 5 years after surgery (Fig. 1A). B-Myb expression was higher in patients who died in comparison to those still alive, but this difference was at the border of statistical significance $(\mathrm{p}=0.0510)$ (Table 2).

Additionally, statistically significant correlations were observed between survival duration and B-Myb and Topo2a levels (Table 1). Survival time was shorter in breast cancers with higher B-Myb and Topo2a values $(\mathrm{p}=0.048699$ and $\mathrm{p}=0.0002321$, respectively) $(\mathrm{Ta}-$

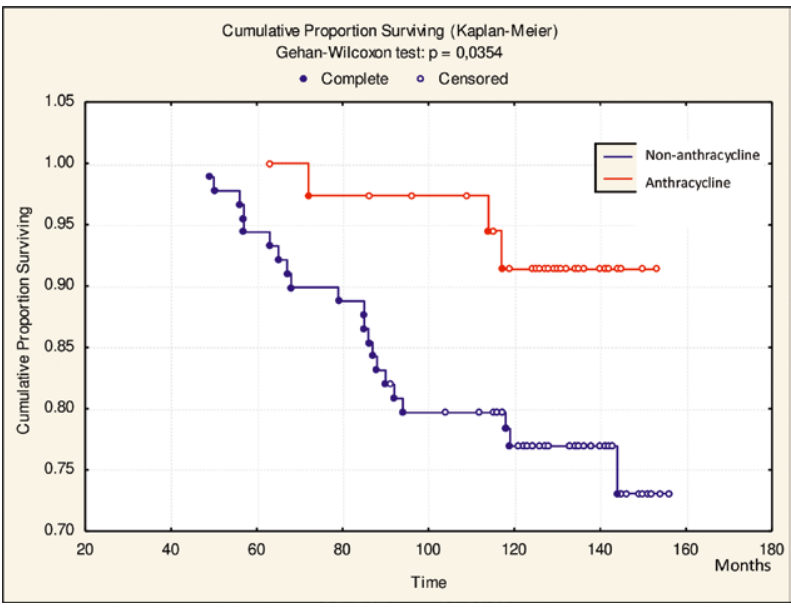

Fig. 3. Overall survival at 48 months according to chemotherapy regimen (anthracycline vs. non-anthracycline).

ble 1). Cases with Topo2a and B-Myb expression above median values (22 and 12, respectively) had lower OS than those with values under the median, but these results did not reach statistical significance ( $\mathrm{p}=0.1954$ and $\mathrm{p}=0.1703$, respectively). Among the $\mathrm{pa}-$ tients who died, a significantly longer survival was seen in those who had received anthracycline-based chemotherapy ( $\mathrm{p}=0.0156)$ (Fig. 2). Additionally, after the first 48 months, patients who had received anthracyclines had higher OS than that those who had not received this treatment (Gehan-Wilcoxon test, $\mathrm{p}=0.0354)$ (Fig. 3). 


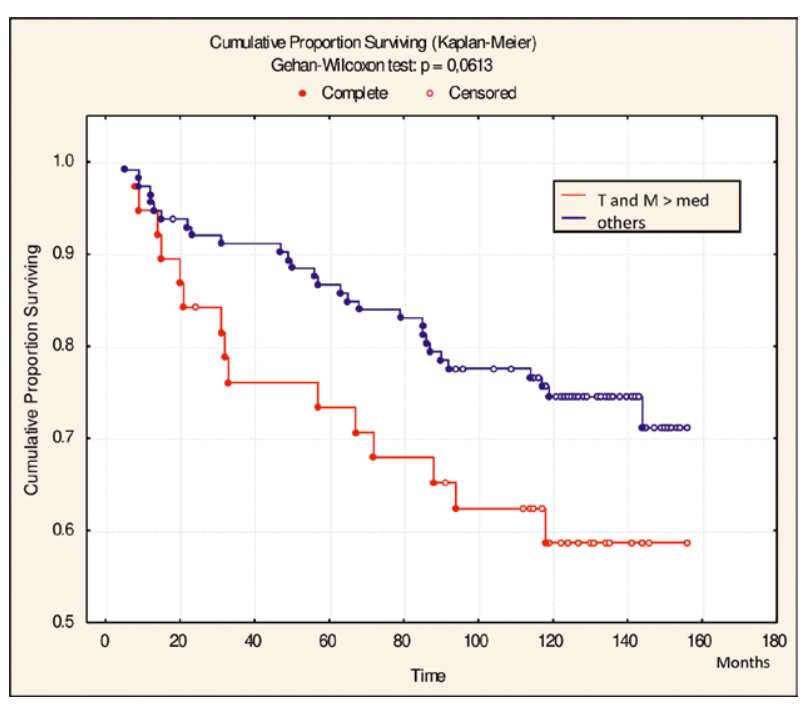

Fig. 4. Overall survival according to combined $B-M y b$ and Topo2a expression: inferior result in those with expression of both proteins above the median value $(n=39)$ as compared with the remaining patients $(n=114)(p=0.0613)$.

\section{Clinical outcomes according to the combined expression of B-Myb and Topo2a}

The cohort was subdivided into four subgroups according to combined $\mathrm{B}-\mathrm{Myb}$ and Topo2a expression, as follows: 0 subgroup, with B-Myb and Topo2a expression under median values $(n=46)$; T subgroup, with only Topo2a above the median value $(\mathrm{n}=36) ; \mathrm{M}$ subgroup, with only B-Myb above the median value $(\mathrm{n}=32)$; and TM subgroup, with both B-Myb and Topo2a above median values $(n=39)$. Kaplan-Meier analysis of the survival curves for these four subgroups showed that they did not differ significantly ( $\mathrm{p}=0.2953)$. The TM subgroup showed inferior survival compared to the rest of the cohort $(n=114)$, but this result was near statistical significance $(\mathrm{p}=$ 0.0613) (Fig. 4).

\section{Discussion}

Breast cancer is not a single disease with several morphological features but a group of molecularly distinct neoplastic diseases, and molecular subgroups with different prognoses require different therapeutic approaches ${ }^{27}$. As per current treatment recommendations, adjuvant systemic therapy is based on tumor stage and biology. However, patient performance sta- tus, comorbidities, and preferences should also be considered $^{28}$.

Despite the use of different prognostic and predictive factors, our ability to predict breast cancer prognosis in each individual patient is limited ${ }^{29}$. Therefore, identifying reliable and efficient prognostic factors remains a major research effort in order to avoid overtreating low-risk patients and enhance the efficacy of adjuvant treatment for those with worse prognosis. The major goal is to increase our understanding of breast cancer prognosis and develop systemic treatments tailored on the basis of predictions of clinical outcomes and risk of recurrence based on tumor aggressiveness. Multigene signature assays (MSA) have changed our risk prediction perspectives with a growing body of evidence, especially through new data predicting the benefits of adjuvant chemotherapy based on the results of multigene signature-based panels ${ }^{30}$.

Avoiding the toxicity of systemic treatment is a key goal in the clinical decision-making process. There is a lot of interest in systemic treatment toxicity avoidance. The $15^{\text {th }}$ St Gallen International Breast Cancer Conference, held in 2017 in Vienna, reviewed new evidence on loco-regional and systemic therapies for early breast cancer and the Conference main topic was 'Escalating and Deescalating Treatment ${ }^{31,32}$. The optimal use of MSA divided the panelists, and although they agreed that all the available multigene assays provided valuable information on the prognosis and risk outside the low-risk subgroup, there was no consensus. By defining the risk, the assays could help us omit chemotherapy in node negative hormone receptor positive HER2 negative early breast cancer. In node positive disease (with 1 to 3 lymph nodes involved), agreement among the panelists was lower, and additional data from current clinical trials in the node positive population are expected to support the decision on chemotherapy ${ }^{31}$.

The use of MSA is not without an additional strain on the healthcare systems. According to real-world data, the use of the 21-gene assay resulted in shorttime incremental costs to the healthcare system, despite lower use of adjuvant chemotherapy ${ }^{33}$. Great efforts are also made to establish assays identifying individuals with micro-metastatic spread, as it may provide additional prognostic information. A very important tool in predicting early breast cancer outcomes could be identification of circulating tumor DNA (ctDNA) 
or circulating tumor cells (CTCs) ${ }^{34,35}$. The abovementioned approaches to identify patients with worse outcomes are expensive and inappropriate for daily routine in many low- and middle-income countries. Additionally, MSA are still not widely available in many countries.

Our small study provided real-world data on the outcomes of early, primary, operable, and invasive breast cancer (intermediate- and high-risk) patients treated with adjuvant chemotherapy (and radiotherapy and endocrine therapy, if indicated).

A limitation of the study was a small sample size, yet it displayed several advantages, e.g., all primary treatments were performed at a single institution (surgery, chemotherapy, radiotherapy, and indication for endocrine therapy), and all patients were referred to our institution with early operable breast cancer over a relatively short period of one year. Thus, all patients were treated according to treatment recommendations valid in that period, thus increasing homogeneity of our study cohort. An additional value of our study was long prospective follow-up for more than a decade in all patients, according to the routine institutional guidelines, providing us with accurate 5- and 10-year survival rates.

We considered the IHC expression of two proliferation markers with prognostic impact, Topo2a as an old and well-known prognostic marker and B-Myb as a novel prognostic marker, and found them to be overexpressed in aggressive breast cancers. Several previous studies showed that Topo2a overexpression served as a predictor of shorter DFS, specific survival rates, and OS rates ${ }^{13-16}$. Remarkably, B-Myb is an inductor of TOP2A gene expression ${ }^{8}$.

Our study results showed that patients with breast cancers overexpressing B-Myb and Topo2a above the median levels based on IHC had worse prognosis than patients without overexpression of these two proteins. Our previous study also revealed that higher IHC expression of B-Myb was linked to worse prognosis (shorter DFS and OS) ${ }^{36}$, as also reported by Thorner et al. ${ }^{8}$.

The results of our study require further validation in larger patient cohorts and within different adjuvant chemotherapy regimens (anthracycline vs. non-anthracycline, etc.). It would also be useful to carry out our analysis across different breast cancer subtypes (luminal B vs. triple negative, etc.), as it could help us select patients with a higher risk of worse outcomes for escalation of adjuvant therapy with more aggressive or novel chemotherapy regimens. In some higher risk patients, escalating adjuvant chemotherapy is an option, as seen in the addition of capecitabine in triple negative breast cancer after preoperative chemotherapy $(\mathrm{CREATE}-\mathrm{X})^{37}$. However, sometimes it is advantageous to de-escalate adjuvant therapy. For example, four courses of chemotherapy (with AC or paclitaxel) can be as good as more courses in terms of OFS and $\mathrm{OS}^{38}$.

In conclusion, our study provides further insight for investigation of the prognostic impact of B-Myb and Topo2a overexpression in breast cancer patients treated with adjuvant chemotherapy.

\section{Acknowledgment}

This study was granted by the Ministry of Science, Education, and Sports, Republic of Croatia (project 108-1080058-0046).

\section{References}

1. Paik S, Shak S, Tang G, et al. A multigene assay to predict recurrence of tamoxifen-treated, node-negative breast cancer. N Engl J Med. 2004;351:2817-26. doi: 10.1056/NEJMoa041588.

2. van de Vijver MJ, He YD, van't Veer LJ, et al. A gene-expression signature as a predictor of survival in breast cancer. $\mathrm{N}$ Engl J Med. 2002;347:1999-2009. doi: 10.1056/NEJMoa021967.

3. Forozan F, Mahlamaki EH, Monni O, et al. Comparative genomic hybridization analysis of 38 breast cancer cell lines: a basis for interpreting complementary DNA microarray data. Cancer Res. 2000;60:4519-25.

4. Zondervan PE, Wink J, Alers JC, et al. Molecular cytogenetic evaluation of virus-associated and non-viral hepatocellular carcinoma: analysis of 26 carcinomas and 12 concurrent dysplasias. J Pathol. 2000;192:207-15. doi: 10.1002/1096-9896 (2000)9999:9999<::AID-PATH690>3.0.CO;2-\#.

5. Tanner MM, Grenman S, Koul A, et al. Frequent amplification of chromosomal region 20q12-q13 in ovarian cancer. Clin Cancer Res. 2000;6:1833-9.

6. Mao X, Orchard G, Lillington DM, Russell-Jones R, Young BD, Whittaker SJ. Amplification and overexpression of JUNB is associated with primary cutaneous T cell lymphomas. Blood. 2003;101:1513-9. doi: 10.1182/blood-2002-08-2434.

7. Sala A. B-Myb, a transcription factor implicated in regulating cell cycle, apoptosis and cancer. Eur J Cancer. 2005;41:2479-84. doi: 10.1016/j.ejca.2005.08.004.

8. Thorner AR, Hoadley KA, Parker JS, Winkel S, Millikan RC, Perou CM. In vitro and in vivo analysis of B-Myb in basal-like 
breast cancer. Oncogene. 2009;28:742-51. doi: 10.1038/onc. 2008.430 .

9. Smith P, Soues S, Gottlieb T, et al. Etoposide-induced cell cycle delay and arrest-dependent modulation of DNA topoisomerase II in small-cell lung cancer cells. Br J Cancer. 1994;70: 914-21. doi: 10.1038/bjc.1994.420.

10. Jarvinen TAH, Liu ET. Simultaneous amplification of HER-2 (ERBB2) and topoisomerase II alpha (TOP2A) genes - molecular basis for combination chemotherapy in cancer. Curr Cancer Drug Targets. 2006;6:579-602. doi: 10.2174/15680 0906778742497.

11. Jarvinen TAH, Tanner M, Rantanen V, et al. Amplification and deletion of topoisomerase II alpha associate with ErbB-2 amplification and affect sensitivity to topoisomerase II inhibitor doxorubicin in breast cancer. Am J Pathol. 2000;156(3):839-47. doi: 10.1016/s0002-9440(10)64952-8.

12. Withoff S, Keith WN, Knol AJ, et al. Selection of a subpopulation with fewer DNA topoisomerase II alpha gene copies in a doxorubicin-resistant cell line panel. Br J Cancer. 1996;74 (4):502-7. doi: 10.1038/bjc.1996.393.

13. Qiao JH, Jiao DC, Lu ZD, Yang S, Liu ZZ. Clinical significance of topoisomerase $2 \mathrm{~A}$ expression and gene change in operable invasive breast cancer. Tumor Biol. 2015;36:6833-8. doi: 10.1007/s13277-015-3390-6.

14. Karnes RJ, Cheville JC, Ida CM, et al. The ability of biomarkers to predict systemic progression in men with high-risk prostate cancer treated surgically is dependent on ERG status. Cancer Res. 2010;15;70(22):8994-9002. doi: 10.1158/0008-5472. CAN-10-1358.

15. Moiseyenko VM, Volkov NM, Suspistin EN, et al. Evidence for predictive role of BRCA1 and bTUBIII in gastric cancer. Med Oncol. 2013;30:545. doi: 10.1007/s12032-013-0545-4.

16. Sherman-Baust CA, Kuhn E, Valle BL, et al. A genetically engineered ovarian cancer mouse model based on fallopian tube transformation mimics human high-grade serous carcinoma development. J Pathol. 2014;233(3):228-37.doi: 10.1002/ path.4353.

17. Rudolph P, MacGrogan G, Bonichon F, et al. Prognostic significance of $\mathrm{Ki}-67$ and topoisomerase II $\alpha$ expression in infiltrating ductal carcinoma of the breast. Breast Cancer Res Treat. 1999;55:61-71.doi: 10.1023/a:1006159016703.

18. Yang Z, Liu Y, Shi C, et al. Suppression of PTEN/AKT signaling decreases the expression of TUBB3 and TOP2A with subsequent inhibition of cell growth and induction of apoptosis in human breast cancer MCF-7 cells via ATP and caspase-3 signaling pathways. Oncol Rep. 2017;37(2):1011-9.doi: 10.3892/ or.2017.5358.

19. Zheng H, Li X, Chen C, et al. Quantum dot-based immunofluorescent imaging and quantitative detection of TOP2A and prognostic value in triple-negative breast cancer. Int J Nanomedicine. 2016;11:5519-29. doi: 10.2147/IJN.S111594.

20. Şahin S, Işık Gönül İ, Çakır A, Seçkin S, Uluoğlu Ö. Clinicopathological significance of the proliferation markers Ki67,
RacGAP1, and topoisomerase 2 alpha in breast cancer. Int J Surg Pathol. 2016;24(6):607-13. doi: 10.1177/106689691 6653211.

21. Romero A, Martín M, Cheang MCU, et al. Assessment of topoisomerase II $\alpha$ status in breast cancer by quantitative PCR, gene expression microarrays, immunohistochemistry, and fluorescence in situ hybridization. Am J Pathol. 2011;178(4):145360. doi: 10.1016/j.ajpath.2010.12.042.

22. Contesso G, Mouriesse H, Friedman S, Genin J, Sarrazin D, Rouesse J. Pathological prognostic factors in breast cancer. I. The value of histological grade in long-term prognosis of breast cancer: a study of 1010 patients, uniformly treated at the Institut Gustave-Roussy. J Clin Oncol. 1987;5:1378-86. doi: 10.1200/JCO.1987.5.9.1378.

23. Elston CW, Ellis IO. Pathological prognostic factors in breast cancer. The value of histological grade in breast cancer: experience from a large study with long-term follow-up. Histopathology. 1991;19:403-10.

24. Carreno G, delCasar JM, Corte MD, et al. Local recurrence after mastectomy for breast cancer: analysis of clinicopathological, biological and prognostic characteristics. Breast Cancer Res Treat. 2007;102:61-73. doi: 10.1007/s10549-006-9310-0.

25. Rimm DL, Camp RL, Charette LA, Costa J, Olsen DA, Reiss M. Tissue microarray: a new technology for amplification of tissue resources. Cancer J. 2001;7:24-31.

26. Eerola H, Heikkilä P, Tamminen A, Aittomäki K, Blomqvist C, Nevanlinna H. Relationship of patients' age to histopathological features of breast tumours in BRCA1 and BRCA2 and mutation-negative breast cancer families. Breast Cancer Res. 2005;7(4):R465-R469. doi: 10.1186/bcr1025.

27. Senkus E, Kyriakides S, Ohno S, et al. Primary breast cancer: ESMO Clinical Practice Guidelines for diagnosis, treatment and follow-up. Ann Oncol. 2015;26 Suppl 5;v8-v30. doi: 10.1093/annonc/mdv298.

28. NCCN Version 3.2017. Breast cancer. https://www.ncen.org/ professionals/physician_gls/pdf/breast.pdf

29. Erić I, Petek Erić A, Koprivčić I, Babić M, Pačarić S, Trogrlić B. Independent factors for poor prognosis in young patients with stage I-III breast cancer. Acta Clin Croat. 2020;59(2):24251. doi: 10.20471/acc.2020.59.02.07.

30. Bhutiani N, Egger ME, Ajkay N, Scoggins CR, Martin RC, McMasters KM. Multigene signature panels and breast cancer therapy: patterns of utilization and impact on clinical decision making. J Am Coll Surg. 2018;226(4):406-12. e1. doi: 10.1016/j.jamcollsurg.2017.12.043.

31. Gnant M, Harbeck N, Thomssen C. St. Gallen/Vienna 2017: a brief summary of the consensus discussion about escalation and de-escalation of primary breast cancer treatment. Breast Care. 2017;12:101-6. doi: 10.1159/000475698.

32. Curigliano G, Burstein HJ, Winer PE, et al. De-escalating and escalating treatments for early-stage breast cancer: the St. Gallen International Expert Consensus Conference on the Primary Therapy of Early Breast Cancer 2017. Ann Oncol. 2017; 1;28(8):1700-12. 
33. Mittmann N, Earle CC, Cheng SY, Julian JA, Rahman F, Seung SJ, et al. Population-based study to determine the health system costs of using the 21-gene assay. J Clin Oncol. 2018; 20;36(3):238-43. doi: 10.1200/JCO.2017.74.2577.

34. Han X, Wang J, Sun Y. Circulating tumor DNA as biomarkers for cancer detection. Genomics Proteomics Bioinformatics. 2017;15(2):59-72. doi:10.1016/j.gpb.2016.12.004.

35. Gold B, Cankovic M, Furtado LV, Meier F, Gocke CD. Do circulating tumor cells, exosomes, and circulating tumor nucleic acids have clinical utility? A report of the association for molecular pathology. J Mol Diagn. 2015;17(3):209-24. doi: 10.1016/j.jmoldx.2015.02.001.
36. Dedić Plavetić N, Jakić-Razumović J, Kulić A, Vrbanec D. Prognostic value of proliferation markers expression in breast cancer. Med Oncol. 2013;30:523. doi: 10.1007/s12032-013-0523-x.

37. Masuda N, Lee SJ, Ohtani S, et al. Adjuvant capecitabine for breast cancer after preoperative chemotherapy. N Engl J Med. 2017;376:2147-59. doi: 10.1056/NEJMoa1612645.

38. Shulman LN, Cirrincione CT, Berry DA, et al. Six cycles of doxorubicin and cyclophosphamide or paclitaxel are not superior to four cycles as adjuvant chemotherapy for breast cancer in women with zero to three positive axillary nodes: Cancer and Leukemia Group B 40101. J Clin Oncol. 2012;30(33): 4071-6. doi: 10.1200/JCO.2011.40.6405.

\title{
Sažetak PROGNOSTIČKA VRIJEDNOST TOPOIZOMERAZE 2-ALFA I B-MYB
U RANOM RAKU DOJKE LIJEČENOM ADJUVANTNOM KEMOTERAPIJOM
}

\author{
Lj. Radmilović Varga, N. Dedić Plavetić, P. Podolski, D. Mijatovic, A. Kulić i D. Vrbanec
}

Rak dojke je najčešći zloćudni tumor u žena. Unatoč dobro definiranim "tradicionalnim” prognostičkim čimbenicima naša mogućnost prognoze za svaku pojedinu bolesnicu je ograničena. U ovom istraživanju smo analizirali imunohistokemijsku izraženost B-Myb-a i DNA topoizomeraze 2-alfa (Topo2a) u primarnim tumorima kako bi se identificirale bolesnice s većim rizikom povrata bolesti nakon adjuvantne kemoterapije za rani invazivni rak dojke. Analizirana je kohorta od 215 bolesnica s ranim invazivnim karcinomima dojke koje su operirane u Kliničkom bolničkom centru Zagreb od 2002. do 2003. godine, uključujući 153 bolesnice koje su liječene adjuvantnom kemoterapijom. Sve su praćene prospektivno najmanje deset godina prema rutinskoj kliničkoj praksi. Dokazali smo statistički značajne korelacije između razine izraženosti B-Myb i Topo2a te nekih „tradicionalnih” prognostičkih čimbenika. Izraženost B-Myb je bila niža u ER pozitivnim tumorima $(\mathrm{p}=0,0773)$, ali su veći tumori, kao i oni s pozitivnom limfovaskularnom invazijom imali statistički značajno veću izraženost proteina $\mathrm{B}-\mathrm{Myb}(\mathrm{p}=0,0409$ i $\mathrm{p}=0,0196)$. Također, pokazali smo da veći gradus tumora ukazuje na višu vrijednost Topo2a $(\mathrm{p}=0,0102$ i $\mathrm{p}=0,0069)$. Pokazali smo da podskupina bolesnica s izraženošću oba proteina iznad srednje vrijednosti ima lošiji ishod bolesti u odnosu na ostatak skupine, ali rezultat je blizu granice statističke značajnosti $(p=0,0613)$. Naše istraživanje je pokazalo prognostičku vrijednost kombinacije prekomjerne imunohistokemijske izraženosti B-Myb i Topo2a u bolesnica s rakom dojke nakon adjuvantne kemoterapije, što zaslužuje daljnja istraživanja na većim skupinama bolesnica.

Ključne riječi: Rak dojke, prognoza, ishod; Adjuvantna kemoterapija; B-Myb; Topo2a 